\title{
Accountability and co-production of information and control: social observatories and their relationship with government agencies
}

\author{
Paula Chies Schommer \\ Universidade do Estado de Santa Catarina / Departamento de Administração Pública \\ Florianópolis / SC - Brasil \\ Arlindo Carvalho Rocha \\ Universidade do Estado de Santa Catarina / Departamento de Ciências Econômicas \\ Florianópolis / SC - Brasil \\ Enio Luiz Spaniol \\ Universidade do Estado de Santa Catarina / Departamento de Administração Pública \\ Florianópolis / SC - Brasil \\ Jeferson Dahmer \\ Universidade do Estado de Santa Catarina / Grupo de pesquisa Politeia \\ Florianópolis / SC - Brasil \\ Alessandra Debone de Sousa \\ Governo do Estado de Pernambuco / Programa Mãe Coruja Pernambucana \\ Recife / PE - Brasil
}

\begin{abstract}
Through the development of a proposal to categorize accountability into four stages - classical, cross-sectional, systemic, and diffused -, this article aims to identify characteristics of co-production of information and socio-political control of public administration in the work of Brazilian social observatories in relationship with government control agencies. The study analyses data from 20 social observatories and, particularly, three experiences of co-production of information and control, based on a systemic perspective on accountability and a model with four categories: Political and cultural; valuing; systemic-organizational, and production. The conclusions summarize characteristics of these practices, specific phases in the accountability processes, as well as the potentialities and challenges of co-production of information and control, which not only influences, but it is also influenced by the accountability system.
\end{abstract}

KEYWORDs: accountability; co-production; control; information; social observatories.

DOI: http://dx.doi.org/10.1590/0034-7612115166

(c) (1)

Article submitted on 9 Apr. 2013 and accepted for publication on 28 May. 2015.

The authors would like to thank Professor Dorothea Greiling for her valuable comments that helped to improve this paper. 
Accountability, coprodução da informação e do controle: observatórios sociais e suas relações com órgãos governamentais

A partir do desenvolvimento de uma proposta de categorização da accountability em quatro estágios - clássica, transversal, sistêmica e difusa - este trabalho objetiva identificar características da coprodução da informação e do controle sociopolítico sobre a administração pública nas relações entre observatórios sociais brasileiros e órgãos estatais de controle. O estudo analisa dados de 20 observatórios sociais e, particularmente, três experiências de coprodução da informação e do controle, com base em uma perspectiva sistêmica da accountability e um modelo em quatro categorias: política-cultural; valorativa; organização sistêmica e produção. A conclusão sintetiza características dessas práticas, fases específicas no processo de accountability, bem como potencialidades e desafios para a coprodução da informação e do controle, que não só influencia como também é influenciada pelo sistema de accountability.

Palavras-chave: accountability; coprodução; controle; informação; observatórios sociais.

Accountability, coproducción de la información y del control: los observatorios sociales y su relación con las agencias gubernamentales

Desde una propuesta de categorización de la accountability - clásica, transversal, sistémica y difusa -, este trabajo tiene como objetivo identificar las características de la coproducción de la información y del control sociopolítico de la administración pública en las relaciones entre los observatorios sociales brasileños y las agencias gubernamentales de control. El estudio analiza datos de 20 observatorios sociales y, más específicamente, de tres experiencias de coproducción, a partir de una perspectiva sistémica de la accountability y un modelo dividido en cuatro categorías: político-cultural; evaluativa; organización sistémica y producción. En la conclusión presentase las características de estas prácticas, las etapas en el proceso de accountability, así como el potencial y los desafíos para la coproducción de la información y del control, que no solo influye, como también es influenciada por el sistema de accountability.

Palabras clave: accountability; coproducción; control; información; observatorios sociales.

\section{Introduction}

The democratization process experienced in Brazil since the 1980s has led to the development of citizenship and democracy, as well as the establishment of conditions for innovations of institutional, political, socio-cultural, and administrative nature. New accountability practices related to transparency, access to public information, fight against corruption, and qualification of control over public administration have been widespread, by means of initiatives of the State or civil society, as well as through an interaction between them.

Examples of such initiatives of the civil society are the network for social control Amarribo Brasil, which has been created through a successful experience in a small town in São Paulo, Brazil (Trevisan et al., 2003), and the network for social control Social Observatory of Brazil (SOB), derived from the experience of the Social Observatory of Maringá (SOM) (Doin et al., 2012). 
The SOM was created in 2006, when a corruption case involving traditional political groups in Maringá city, Paraná, Brazil led to the mobilization of civil society organizations, businesses, and government agencies, in order to promote civic engagement for better control over the local public administration. The methods and achievements of the SOM inspired the creation of similar observatories in other municipalities and the establishment of the network SOB, which by 2014 was present in more than 80 municipalities within 15 Brazilian states (OSB, 2014; Doin et al., 2012).

Moreover, some of the public administration agencies devoted to control have worked to increase social engagement. An example is the Brazilian Office of the Comptroller General of the Union (CGU), which supports and works along with civil society organizations regarding various activities, such as supervision and support for municipalities to comply with the requirements of the Law Regulating Access to Information, and the organization of the Brazilian National Conference on Transparency and Social Control (Consocial) (Schommer, Dahmer and Spaniol, 2014; Loureiro et al., 2012).

Therefore, the efforts to build democratic accountability in the country may be analysed focusing on the variety of innovative ways how citizens and governments interact to exercise control over the public administration (Goetz and Jenkins, 2001; Keane, 2009; Cider, 2011; Fox, 2014). This interaction generates opportunity for a mutual engagement between government agencies and citizens, sharing resources, knowledge and responsibilities to coproduce information and control (Rocha et al., 2012; Doin et al., 2012), affecting the entire accountability system.

This allows a new interpretation, moving forward from the classical understanding of vertical and horizontal accountability (O'Donnell, 1998) and focusing on the multiple interactions between agents and control mechanisms, which express new possibilities for accountability - hybrid, diagonal (Goetz and Jenkins, 2001), cross-sectional, social (Cider, 2011; Fox, 2014), relational (Moncrieffe, 2011), or systemic (Rocha et al., 2012).

This approach corroborates the concept of monitory democracy, where the mechanisms for power monitoring and power control expand and permeate the entire political system (Keane, 2009). It is consistent with the view of accountability as something complex, local, and co-produced by several agents in open and innovative processes (Denhardt and Denhardt, 2003).

This article focuses on exploring the details of conditions, procedures, and effects of co-production of information and control, regarded as public goods that are essential for accountability. It involves a mutual and continuous engagement between regular producers of information and control in public administration (government agencies) and users or those interested in information and control (citizens, individually or organized into councils, groups, and associations). This process of a mutual engagement is what may happen through the action of observatories that make up the network SOB, interacting with government agencies, affected by characteristics of the local and national accountability system and contributing to shape it.

This article aims to identify (through a proposal to categorize accountability into four stages) characteristics of co-production of information and control of public administration in the work of social observatories, when they interact with government control agencies. 
This descriptive and qualitative research, conducted from 2009 to 2014, was based on literature addressing co-production and accountability; data from twenty social observatories; videos, interviews, participation in meetings, and documentary analysis. Three experiences of co-production of control are detailed herein: a) the relationship between the Social Observatory (SOM) and the Maringá City Hall to create a warehouse and manage stock control of public materials; b) the relationship between the Social Observatory of Itajaí (SOI) and the Public Prosecutor's Office of Santa Catarina to control government spending in the city; and c) the relationship between the Social Observatory of São José (Sosj) and the Municipal Internal Control Agency to reduce public spending on electric power, water supply, and telephonic communication.

The analysis has a literature-based framework that proposes four stages of accountability - classical, cross-sectional, systemic, and diffused - , and a model developed by Rocha and partners (2012), adapted for this study. This model consists in four dimensions: political and cultural, the possibilities and ways of incorporating accountability in the Brazilian political culture; valuing, which is related to the meaning and consequences of considering control as a public good; systemic-organizational, the ways of connecting accountability tools in a systemic manner, their connection to networks, and their governance; and production, regarding the operation of experiences of co-production of control.

The conclusions summarize characteristics of these practices, identifying specific phases in the accountability processes, as well as pointing out potentialities and challenges of coproduction of public administration control.

\section{Accountability and co-production of information and control of public administration}

Accountability may be understood as a strategy to meet a set of expectations (Heidemann, 2009); as an obligation a person or group have to be accountable for responsibilities entrusted to her/him/it by others (Kluvers and Tippet, 2010); or as a condition that limits power by applying internal rules and external pressure (Koppell, 2005). In the public sphere, democratic accountability is one of the pillars to improve public administration and the democracy itself. Democratic accountability may be understood as a series of mechanisms through which public agents are constrained to continuously render account and be rewarded or sanctioned for their acts and omissions towards the citizens (Abrucio and Loureiro, 2005).

The production and dissemination of good-quality, trustworthy, and reliable public information to citizens is one of the conditions for effectiveness of accountability (Abrucio and Loureiro, 2005). The use of such information contributes to shape a more conscious public opinion, allows monitoring political promises and government plans, as well as public policies and services, and assigns responsibilities to public agents. Such information also contributes to decision-making and it has the potential to improve public administration and public welfare. Thus, the production and dissemination of public information may be seen as a public good, 
since it is a condition for control over power, which in turn is crucial for constructing fair and sustainable societies.

Traditionally, public information is produced by State agencies of institutional control, and any contribution by society is incidental. Such contribution may be more effective and present when society engages with public agents to co-produce information and control.

Co-production of public goods and services is based on a mutual and active engagement between government and citizens, individually or through associative or economic organizations, organized into partnerships or networks (Brudney and England, 1983; Marschall, 2004; Roberts, 2004; Denhardt and Denhardt, 2003; Salm and Menegasso, 2012; Verschuere, Brandsen and Pestoff, 2012). This requires institutional arrangements and public governance strategies that constitute an alternative to hierarchical management, using and promoting cooperation, fostering joint action and coordination between civil society, businesses, and government (Kissler and Heidemann, 2006; Rhodes, 2006; Denhardt, 2012).

Co-production requires an organized and permanent engagement of citizens, not only bringing demands and establishing priorities, but also directly participating in the production or delivery of public goods and services and promoting shared power with the government (Verschuere, Brandsen and Pestoff, 2012). Co-production goes beyond citizens using their voices. It is a hands-on approach. Thus, a citizen becomes active in the transformation of reality, considering, thinking, and changing values that reflect interests and expectations of a society (Brudney and England, 1983).

When it is assumed that the production, dissemination, and use of good-quality information to control public administration may be provided through interaction between State agencies and by citizens, new ways of control over governments are generated. The co-production of sociopolitical control of public administration depends on the relationship between: a variety of social actors, public agencies, and administrative facilities; technical and political elements; and a combination of legal, institutional, and informal elements. These elements comprise an interdependent system that depends on the performance and relationship of each of its parts (Child and McGrath, 2001).

Sometimes, experiences of co-production are sporadic, limited, and fragile, affecting the entire accountability system, which entails investigation of the types and intensity of co-production of information and control and their implication in terms of stages in the accountability process. Co-production tends to be more complete as far as there is progress in terms of technical capacity, political and institutional maturity, and relationship among the several agents and mechanisms involved, on a continuous learning process (Rocha et al., 2012). There is also a possible relationship of a mutual influence: the multiplicity of interactions in the system forges co-production; the occurrence of co-production increases the capacity of public and community agents to understand and act on the system itself, making it more dynamic.

These assumptions have led to the proposal of a theoretical approach to accountability into four stages. 


\subsection{Accountability: classical, cross-sectional, systemic, and diffused}

A classic difference between accountability mechanisms proposed by O'Donnell (1998) uses a metaphor from Geometry to distinguish accountability by the State (horizontal accountability) from that where citizens act over public agents, including elections and forms of social control during the mandates (vertical accountability). This metaphor, although widely disseminated and useful to understand accountability, is limited, since it overshadows power asymmetries between public agents and control mechanisms in the State (horizontal axis). It also overshadows the diversity of roles and forms of interaction in the State-society relationship (Ceneviva, 2006), which is not restricted to the vertical axis of influence and control over power.

Thus, this may be seen as the first stage of connection between accountability mechanisms. At this stage, there is no co-production of information and control, as it is displayed at stage 1 in figure 1 and at stage 1 in chart 1 (traditional accountability).

When the production, dissemination, and use of information stem from public agents and citizens, the vertical and horizontal mechanisms of control can interact, creating new forms and a new axis of control over State and government activities. This may be seen as a second stage of connection between these mechanisms - cross-sectional accountability (stage 2 in figure 1 and stage 2 in chart 1 ).

\section{Figure 1}

Illustration of the classic mechanisms of accountability (1) and the cross-sectional interaction between them (2)

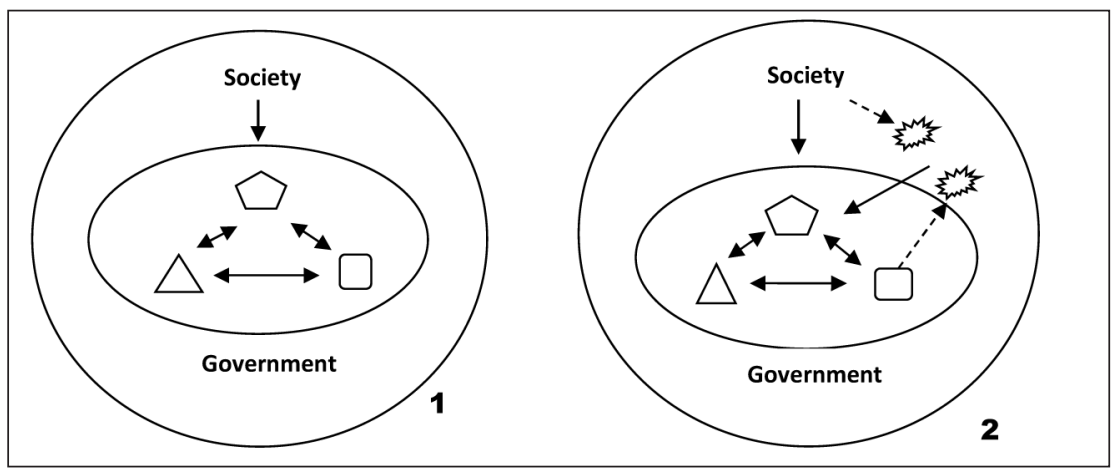

Source: Prepared by the authors.

At stage 3 in figure 2 and at stage 3 in chart 1 (systemic accountability), citizens and government work together, with complementary and interconnected roles, in order to produce information and control. 
Figure 2

Illustration of the multiple interactions among accountability mechanisms in a systemic way (3) and as an ideal type, diffused (4)

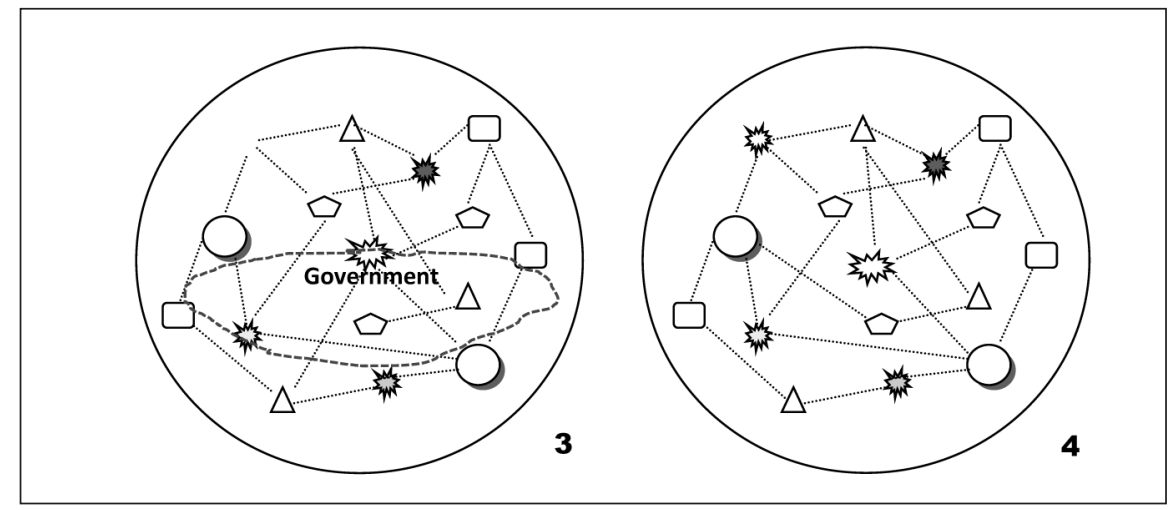

Source: Prepared by the authors.

This kind of structure is similar to a network, involving a variety of political-institutional mechanisms and several structures and strategies of public governance (Kissler and Heidemann, 2006; Denhardt, 2012), influencing each other in a systemic way (Child and McGrath, 2001).

Thus, it is worth referring to the concept of monitory democracy proposed by Keane (2009), which consists in a variety of innovative ways how citizens and control agencies can communicate and coordinate themselves to provide control. In monitory democracy, powermonitoring and power-controlling devices extend sideways and downwards through the political order (Keane, 2009). This is consistent with a view of accountability as something complex, innovative, contextualized and co-produced by a range of agents, an image aligned with the approach by the New Public Service (Denhardt and Denhardt, 2003). This approach proposes moving away from hierarchical accountability, based on conformity and a separation between administration and politics, typical of the Old Public Administration, and beyond market-driven accountability, typical of the New Public Management (Rocha, 2011). Likewise, the concept of relational accountability (Moncrieffe, 2011) shifts the focus of institutional framework on accountability to the quality of relationships between agents in each context.

The quality of co-production of information and control — from a systemic viewpoint - is defined by the role played by each party involved in the process and the quality of the relationship between them. Thus, if the relationship between parties is fragile, the potential for co-production is hindered. Since there are various possibilities of interaction, the roles of those involved may vary from one situation to another. Once established, the rules, criteria, and responsibilities are monitored, assessed, and subject to change as a result of the interaction between agents.

The existence of various agents and mechanisms that produce information, control, and accountability brings up the image of a transitory center rather than a vision focused on mechanisms of control from and over the State. This is closer to the multidimensional view 
proposed by Ramos (1981) for the analysis of social systems. According to Ramos (1981), the role played by governments should be promoting conditions for transactions between the various social enclaves that make up a multi-centered society.

Co-production of control is favored and favors transactions between various enclaves, undermining the State's centrality, but strengthening control by involving citizens who choose to engage. Ramos (1981) notices there is a place in the social world for citizens to act free of roles, rules, and regulations imposed by a super-organized society. This allows citizens to redefine identities, express interests, and connect to others to produce the goods and services they want, becoming co-responsible for the process and results.

As an extreme viewpoint, this may be regarded as an ideal type, i.e. diffused accountability (stage 4 in figure 2 and stage 4 in chart 1), where the production of information and control is equally shared by State and society, without a central structure and regular procedures.

Chart 1

The four stages of the incorporation of accountability in the political culture

\begin{tabular}{|c|c|}
\hline $\begin{array}{l}\text { 1. Traditional } \\
\text { accountability }\end{array}$ & $\begin{array}{l}\text { There is no co-production of information and control. The level of interaction between the mechanisms } \\
\text { of social and institutional control is low, just as the capacity of influence of social control over the } \\
\text { agencies of institutional control. The State apparatus is responsible, almost exclusively, for information } \\
\text { and control. There is an emphasis on the election process as a mechanism of punishment or reward. }\end{array}$ \\
\hline $\begin{array}{l}\text { 2. Cross-sectional } \\
\text { accountability }\end{array}$ & $\begin{array}{l}\text { There is sporadic and peripheral co-production of information and control. Interaction between } \\
\text { mechanisms of institutional control and social control shows different levels of regularity and resource } \\
\text { sharing. The capacity of influence of social control over the institutional control system increases, } \\
\text { but the latter maintains its structure. The State apparatus is responsible for information and control, } \\
\text { eventually sharing its activities with civil society organizations. There is a higher degree of society } \\
\text { influence over the institutional mechanisms of justification and sanction. }\end{array}$ \\
\hline $\begin{array}{l}\text { 3. Systemic } \\
\text { accountability }\end{array}$ & $\begin{array}{l}\text { There is co-production of information and control, in various ways and at different levels of } \\
\text { institutionalization. A mutual engagement between citizens and public servants continuously affects } \\
\text { the impact and results of the States functions, contributing to shape the structure and make the } \\
\text { State action limits more sensitive, fluid, and permeable to the society's interests. The State apparatus } \\
\text { and its specific responsibilities are present, but it assumes a more flexible form. Given its organic } \\
\text { nature, if one part of the control system fails, the entire system is affected and the other parts try } \\
\text { to assure that the system works. However, in case of failure of one part, its role may be performed } \\
\text { by other parts of the system. }\end{array}$ \\
\hline $\begin{array}{l}\text { 4. Diffused } \\
\text { accountability }\end{array}$ & $\begin{array}{l}\text { This is an ideal type of accountability. Information and control are produced by various agents } \\
\text { without a central structure and regular procedures. Co-production is exercised with a low degree of } \\
\text { institutionalization and it does not necessarily involve the State apparatus. }\end{array}$ \\
\hline
\end{tabular}

Source: Prepared by the authors.

These arguments raised a set of issues, instigating the exploration of ongoing experiments in Brazil, which point to potentials and limits of co-production of information and control. In addition to the issues, clues that enable sketching a categorization are introduced below. 


\section{Categories for analysis of experiences of co-production and methodological aspects}

In order to conduct the research about experiences of co-production, some guiding questions, adapted from Rocha and partners (2012), were adopted. These questions seek to shape general statements about: a) the forms and possibilities to incorporate accountability in the Brazilian political culture; b) the meaning and consequences of considering control of public administration as a public good; c) the possibilities and forms of systemic relationship of the accountability mechanisms, sharing of values, interconnection within networks, governance for co-production; and d) the possibilities and forms of co-production of information and control. These questions are grouped into four categories of analysis, displayed in Chart 2 and figure 3 .

Chart 2

Categories for analysis of co-production of information and sociopolitical control of public administration

\begin{tabular}{|c|c|c|c|}
\hline & \multicolumn{2}{|c|}{ Categories } \\
\hline \multirow{3}{*}{$\begin{array}{l}\text { Political and } \\
\text { cultural } \\
\text { Incorporation of } \\
\text { accountability } \\
\text { in the Brazilian } \\
\text { political culture, } \\
\text { as the base for } \\
\text { the process of } \\
\text { co-production } \\
\text { of information } \\
\text { and control as } \\
\text { a public good, } \\
\text { grounding and } \\
\text { permeating the } \\
\text { other categories. }\end{array}$} & Valuing & $\begin{array}{l}\text { Refers to the meaning and the significance of } \\
\text { taking into account information and control } \\
\text { of public administration as public goods. } \\
\text { It involves not only the meaning, i.e. what } \\
\text { it is referring to and what is the impact of } \\
\text { regarding information and control of public } \\
\text { administration as public goods; but also the } \\
\text { significance, or the value, of this conception } \\
\text { and its consequences. }\end{array}$ & $\begin{array}{l}\text { What is the meaning and significance of taking } \\
\text { into account information and control of public } \\
\text { administration as public goods? } \\
\text { How do citizens, bureaucrats, and politicians feel } \\
\text { when the production of public information and } \\
\text { oversight of public administration are regarded } \\
\text { as a function not solely of the State? }\end{array}$ \\
\hline & $\begin{array}{l}\text { Systemic } \\
\text { organization }\end{array}$ & $\begin{array}{l}\text { Refers to the ways how interactions between } \\
\text { agents and mechanisms of accountability } \\
\text { happen, networks and governance for co- } \\
\text { production - roles, responsibilities, rules, ways } \\
\text { of acting or management practices. }\end{array}$ & $\begin{array}{l}\text { Which are the forms of systemic articulation } \\
\text { of agents and how are the networks and } \\
\text { governance for co-production of sociopolitical } \\
\text { control established? }\end{array}$ \\
\hline & Production & $\begin{array}{l}\text { Concrete and specific experiences of co- } \\
\text { production of information and sociopolitical } \\
\text { control of public administration and the } \\
\text { lessons they can offer. }\end{array}$ & $\begin{array}{l}\text { What the experiences of co-production of } \\
\text { information and sociopolitical control are, and } \\
\text { what do they teach us? }\end{array}$ \\
\hline
\end{tabular}

Source: Adapted from Rocha and partners (2012).

These categories (where the Political and cultural pervades and underlies all others) interact and influence each other, highlighting the dynamic nature of co-production. 
Figure 3

Categories and issues that guide the discussion on co-production of control

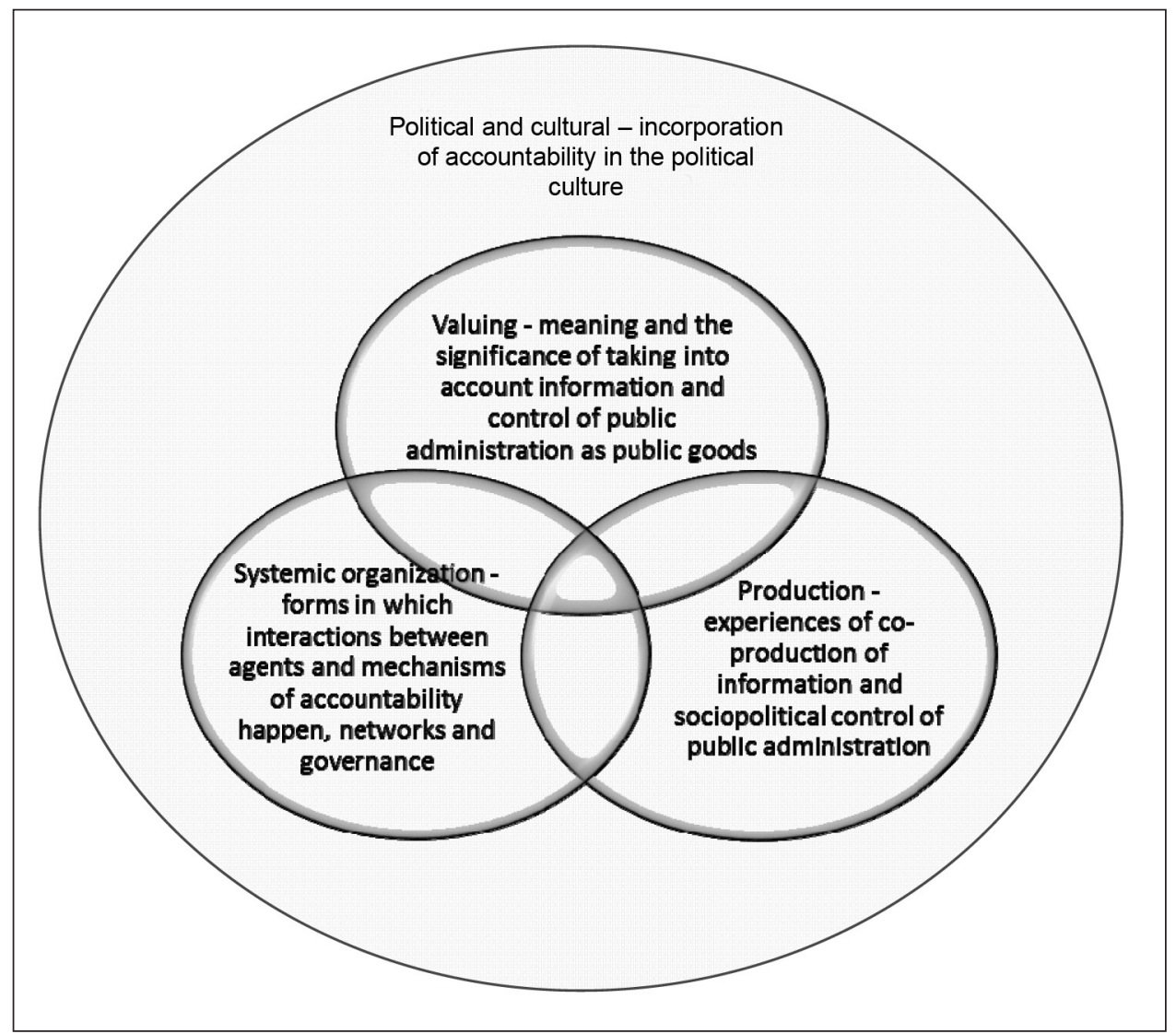

Source: Adapted from Rocha and partners (2012).

The construction of this model of analysis is one of the methodological steps of this research, conducted from 2009 to 2014, consisting in a descriptive and qualitative approach divided into four main phases:

i) Conceptual: regarding the concepts of co-production, accountability, and control, and the Brazilian sociopolitical and institutional context;

ii) Empirical-documentary: searches on websites, videos, news, and discussions by e-mails exchanged between members of the social observatories; participation in events; field research on three social observatories, as well as documentary research and interviews; participation in the creation and management of a social observatory; a survey with twenty observatories that are members of the network SOB;

iii) A model of analysis was created having the previous phases as a basis; 
iv) Then, the research on co-production of information and control was intensified, focusing on the experience of social observatories in Maringá, Itajaí, and São José.They were chosen because they are examples of co-production identified at the first phase of the research and for ease of access. Data on the cases was obtained from documents, videos, media reports, and interviews with observatory members and partners.

\section{Social observatories and the network Social Observatory of Brazil}

The network for social control SOB is made up by civil society organizations that have been replicated in about eighty cities in Brazil since 2006, inspired in the pioneering experience of the SOM, in the state of Paraná, southern Brazil.

The activities of social observatories may include: demanding information from government institutions, politicians, and public officials; pressuring the institutionalized control system to fulfill their roles, including enforcement and punishment; monitoring the public administration - government targets, purchasing contracts, and public expenses; monitoring the quality of the public administration of cities and social welfare indicators; promoting citizen participation in public governance and systemic control, dialoguing with public agents and taking part in decision-making procedures; collecting and preparing data and performance indicators to compare to official data and pointing out the society needs; promoting fiscal citizenship, in activities such as recreational lectures at schools and debates on media and events (Schommer, Nunes and Moraes, 2012; Doin et al., 2012).

Among the twenty members of the network SOB who answered to a structured questionnaire applied in 2010, 55\% said the main reason for their creation was the existence of irregularities in the municipal public administration (corruption, lack of transparency, and bad quality public services) and $45 \%$ were encouraged by initiatives such as the network SOB itself.

In the communication of social observatories that make up the network SOB, there is an effort to demonstrate the results of their work in terms of improved quality of public administration, particularly by demonstrating the savings obtained in the municipality through better expenditures during a specific time period, due to better control over public sector bids.

Many of the observatories keep strong ties to public and private local organizations, in order to legitimize their political action and to raise funds. Organizations like the Rotary Club, Freemasonry, and business associations are frequent supporters. Unions, universities, companies, and other civil society organizations make up the remaining organizations that participate. The activities are carried out through voluntary work (Schommer, Nunes and Moraes, 2012).

An apparent feature of the main observatories is their link to local elite groups. Population portions that are traditionally distant from the local government are also not present in the observatories. There is also the risk that these organizations reproduce old political practices, 
such as elitism, corporatism, and lack of transparency in their actions. Many of them have a dichotomic view between technical and political aspects of public administration (Schommer, Nunes and Moraes, 2012), which corresponds to a conservative view or a primary stage of accountability (Behn, 1998).

An essential feature of social observatories is their interconnection to the network SOB and partnerships with institutional oversight organizations to reinforce their actions. Among the twenty observatories under analysis, some partnerships are restricted to a specific occasion; others gradually take features of a dynamic control system. As for the technical/ managerial cooperation, the most usual relationships involve other observatories, the CGU, and local business associations. When it comes to financial cooperation, the relationship with local business associations and companies stands out. Information sharing is more usually established with other observatories, media/press, and local business associations. As for monitoring carried out by social observatories, the usual partners are city halls and city councils (Schommer, Nunes and Moraes, 2012).

The observatories recognize the importance of their work combined with State control agencies - administrative, legislative, and judiciary - including law enforcement and guaranteeing appropriate sanctions, whenever needed. According to $94 \%$ of respondents, partnerships must be improved and expanded.

In order to explore the features of initiatives of co-production of information and control involving social observatories, the next section discusses the cases of Maringá, Itajaí, and São José.

\subsection{The Social Observatory of Maringá}

The SOM was created in 2006, in order to fight corruption, engage the population in fiscal citizenship, and to improve the administration of public resources in the city. Its founders were members of the local business association and they were moved by a local corruption scandal. They decided to engage in the investigation to be sure that the people involved were punished and to work to avoid other corruption cases in the city.

The SOM has been recognized by the United Nations Economic Commission for Latin America and the Caribbean (Eclac) and the Kellogg Foundation, that granted the SOM with the social innovation award in 2010. The award highlighted its ability to mobilize volunteers and promote community participation and its work of raising awareness about the quality of public administration. In addition, the award emphasizes the methodology used to control local government's purchase contracts and to propose immediate and concrete measures to solve dysfunctional situations, not limited to formal complaints in the ordinary legal instances that are sometimes far from the citizens. The SOM work was also recognized due to the prevention of mismanagement in government purchasing procedures, stimulating transparency, promoting ethical behavior among public servants, and disseminating the 
importance to pay taxes (Marulanda and Tancredi, 2010). The SOM won other prizes and it has inspired the creation of social observatories in other municipalities, leading to the establishment of the network SOB.

One of the most successful initiatives undertaken in Maringá was the creation of a purchasing center and better management of local government warehouses, which derived from a partnership of the SOM and the City Hall, involving local companies and other partners. The SOM identified that, in 2007 and 2008, the local government did not have any inventory control in most of its twenty warehouses around the city. An investigation was carried out and problems were identified: the acquisition of overpriced products and without competitive bidding; products stored in amounts far exceeding the demand and not correctly and systematically controlled; moldy, expired, and damaged goods. In the uncontrolled inventory there was, e.g. 14,436 bottles of expired ethanol; whiteboard markers that were worth the equivalent of 133 years; and thousands of goods that were discarded.

In order to solve these problems, the SOM has partnered with the Maringá City Hall and expert auditors from private companies. The first step was gathering the entire inventory in a central warehouse and using computers to keep track of the goods. The second was discussing a law that states the obligation, for the city's direct and indirect administration, to maintain inventory control. The law was approved by the Maringá City Council and sanctioned by the mayor; it provides rules for the control of inventories of goods purchased by the Maringá City Hall and establishes standards and criteria in the bidding process.

The Maringá City Hall created the Secretariat for Goods, Supplies, and Logistics, which took over the coordination of the purchasing process. Information is now systematized through a software that provides inventory control and makes it possible to know the exact amount of each product in storage. The SOM visits the warehouse periodically and any citizen can access updated information about the city's inventories, except regarding the materials stored within the 100 schools in Maringá, which are not in the software, yet.

The warehouse in Maringá provided the other municipalities with a model to increase storage efficiency. Over 2013, representatives of 15 municipalities visited the city to find out more about the experience.

Co-production of information and control is observed in this experience, where there several agents involved: the SOM, the Maringá City Hall, and specialized auditors from the private sector, as well as the Maringá City Council and citizens, all with the role of controlling government actions. Figure 4 shows the investments of the main partners and the results of the co-production process.

Just as in the experience of co-production in the purchasing and storage system described, the SOM works in other areas and establishes several connections to public administration agencies, companies, and civil society organizations, engaging volunteers and professionals and influencing the entire accountability system. 
Figure 4

Co-production of information and control in Maringá

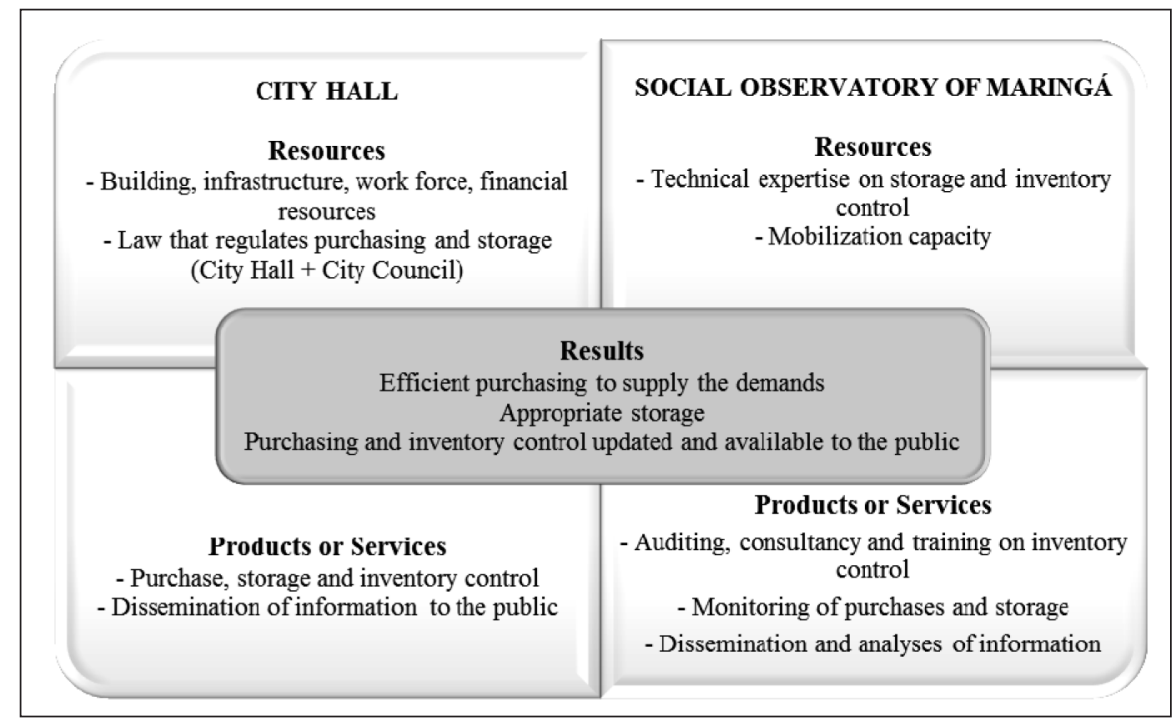

Source: Prepared by the authors.

\subsection{The Social Observatory of Itajaí}

Since its creation, in 2009, the SOI works mainly on monitoring competitive bids in the city. The SOI carefully analyses all bidding phases involving the Itajaí City Hall, the Port of Itajaí, the Itajaí City Council, and the Water and Sanitation Company, it asks for clarification, makes suggestions to the purchasing personnel, and encourages the participation of companies. The work is carried out by interns and volunteers, who follow the operational standards of the network SOB, which include the use of a shared web system to control competitive bids.

The SOI keeps an intimate and informal relationship with the Itajaí City Hall, which has been regarded as effective, according to the interviews. The SOI is aware of the need to establish work relationships with other agencies, in order to achieve effective control, to respond to requests for information in an easier way, and to increase competition in the bids. Moreover, the SOI recognizes that partnerships are needed to make sure that sanctions will be applied to the responsible parties when illegalities are found and to improve the use of public money. Thus, the SOI is working closely along with the Public Prosecutor's Office of Santa Catarina (PMSC), at the Prosecutor's Office for Public Morality.

As the PMSC does not have infrastructure to oversight the local government competition bids, the SOI provides detailed information about the problems it identifies. By 2014, this partnership had over fifty complaints from the SOI filed by the PMSC. Most of them resulted in a probe by the PMSC and around 10\% resulted in a civil lawsuit. According to a respondent, "the PMSC do not know anything about bids, the Public Prosecutor's Office do not collect any 
information about them [...] in this sense, their work is poor." On the other hand, "our role is social control [...] the Public Prosecutor's Office is institutional, constitutional, it has to do its job, and I think we have to step up to help [...] in fact, we help them because they help us."

Figure 5 shows the investments of each partner and the results of the co-production process.

Figure 5

\section{Co-production of information and control in Itajaí}

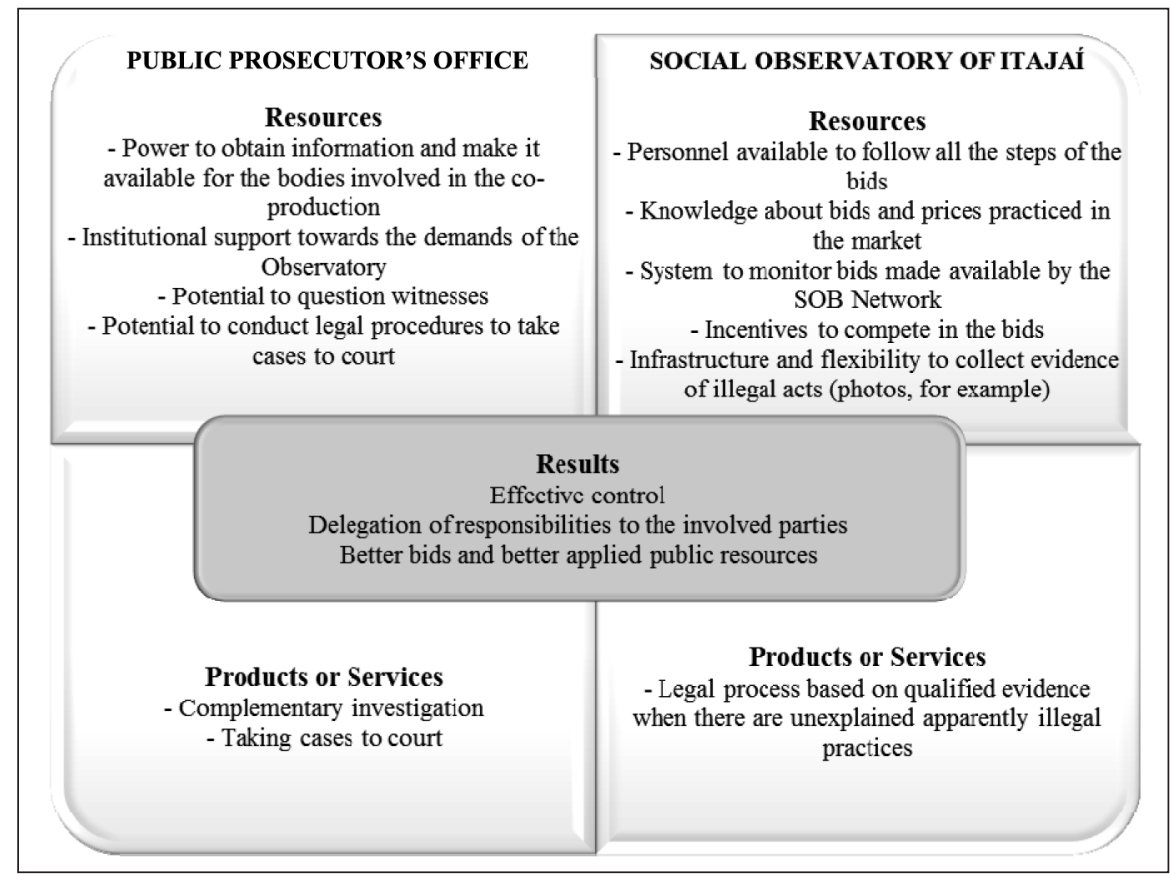

Source: Prepared by the authors.

The interaction between the Public Prosecutor's Office and the SOI shows that the collaborative relationship is personal rather than institutional, something that has been progressively transformed, based on the growing confidence and the results achieved. In this regard, Itajaí has inspired a wider collaboration between the PMSC and several other social observatories in the state of Santa Catarina.

According to the SOI, the partnerships that social observatories establish with other control bodies have fragile boundaries and they deserve attention. The SOI keeps a technical partnership with the CGU to provide training, which it intends to strengthen. There is no regular relationship with the State Court of Auditors. Regarding the Itajaí City Council, the SOI monitors bidding and works to guarantee compliance with laws concerning accountability in the public administration.

There is concern about the risk for social observatories in taking roles that should be played by their partners. Thus, the SOI helps the PMSC in issues related to the bids presented 
by local government, but it is aware that the social observatory is not part of the PMSC, even though, according to a respondent, sometimes the PMSC demands from the SOI as if it were.

This concern is also valid with regard to the bodies that are supervised by the SOI: "We are not going to replace anybody in the city hall. We want them to work properly."

It seems that the SOI has played a strong and bold leading role and its work has become recognized. However, at the same time, the SOI has received much criticism from city councilors in Itajaí. Critics argue that the SOI has a viewpoint that favors some specific groups of interest.

Regarding the annual legal supervision of accounts in the Itajaí City Council, the SOI requested that the council make its accounts available to the civil society for 60 days, something which is a constitutional provision. After three years, the SOI managed to include this prerogative in the Itajaí City Organic Law. This shows both the progress and the difficulty in achieving what has been named "accountability awareness."

\subsection{The Social Observatory of São José}

The activities of the Sosj, created in 2011, focus on the work of the São José City Hall and the São José City Council. The Sosj oversees public contracts with higher costs or those strategically relevant for the city. It also assesses larger expenditures of the city, such as personnel. In addition, the Sosj seeks to make sure the São José City Hall and the São José City Council comply with the Law Regulating Access to Information and put pressure on control agencies such as the Public Prosecutor's Office, the Court of Accounts, and the Legislative Power to control public administration. The work of the observatory has been widely disseminated by the local media and partner networks, primarily the local commercial association.

According to the Sosj, there is an intense relationship of supervision over the São José City Council, but no institutional relationship aimed at co-production. One example concerns the analysis of information supplied by the São José City Council on the government transparency web portal, pointing out that some of the items that should be available for citizens to access were not displayed there.

Co-production of information and control is observed in a partnership between the Sosj and the Municipal Internal Control. In 2013, the new local administration wanted to reduce costs of utility bills such as telephonic communication, water supply, and electric power. Aware of the work done by the observatory, the mayor invited the Sosj to conduct a study and audit these accounts, in partnership with the Municipal Internal Control. The Sosj staff developed a form to collect information and map the units for consumption in every building of the São José City Hall, including schools and healthcare centers. After mapping the units for consumption, the Sosj visited all the units consuming water and electric power. The São José City Hall provided a vehicle for the Sosj to make these visits. Several irregularities were found, mainly regarding payments made for bills that were not under the responsibility of the São José City Hall anymore - e.g. buildings that were rented for a certain period. 
Using the information provided by the Sosj, a detailed report on all irregularities found was produced and suggestions on how to proceed for each case were made, which enabled the Municipal Internal Control to start organizing the situation and solving the problems. In order to disseminate the activity, the Sosj developed a dashboard of the savings generated by the initiative and a simplified guide of the steps adopted, so that other cities could use the model. Figure 6 shows the investments of each partner and the results of the co-production process.

\section{Figure 6}

\section{Co-production of information and control in São José}

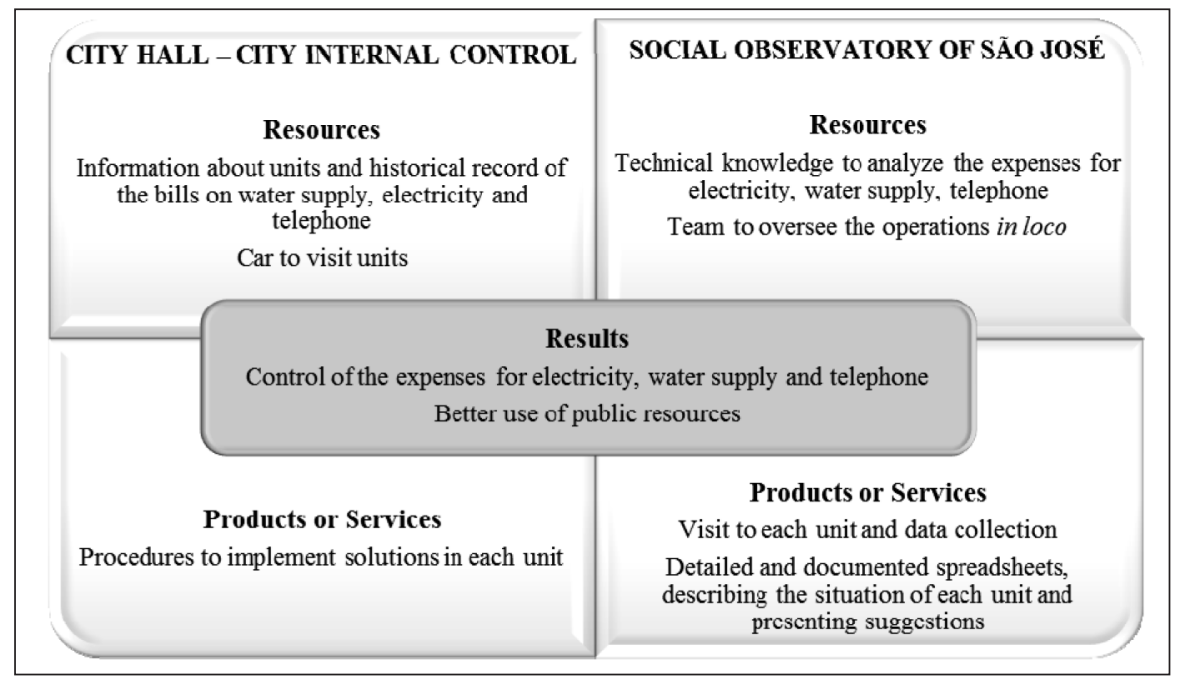

Source: Prepared by the authors.

Despite the results achieved, this experience of co-production was discontinued in 2014, mainly due to criticism. Some of the civil society organizations in the city claim this kind of activity has very little to do with social control, and it is similar to consultancy (therefore, this is not a role that should be played by a social observatory). Criticism was also published in one of the local newspapers, suggesting the observatory had a hidden interest and risked losing autonomy by acting so closely along with the São José City Hall; the latter was also criticized due to its close relationship with the Sosj.

Above all, working in partnership with the Municipal Internal Control helped to build a better relationship with the São José City Hall, and it also allowed the Sosj to learn about the internal procedures. At the same time, the Municipal Internal Control relied on better information and legitimacy to play its role.

The opinion of the observatory directors when it comes to social control is that the major changes in any government should come from the society. The social observatories are crucial in this process, because they address two specific problems in public administration: inefficiency and corruption, which are facilitated by the lack of transparency and malfunction 
of the current controlling agencies. "In this context, the observatories add value to control process and foster transparency," claims a respondent.

Finally, it may be said that, in São José, there was a clear experience of co-production of information and control, with satisfactory results, but they have not been continued. There is an intense supervision over the São José City Council and the São José City Hall, and no institutional relationship between the Sosj and the São José City Council or between the Sosj and the State Court of Auditors, in order to co-produce or share information or activities. There are activities in a mutual support for citizens' education, intervention in the media, and a recent formal partnership involving the Public Prosecutor's Office and several social observatories, in order to monitor the municipal web portals, with an active role played by the Sosj. In addition, it has been seen that the Sosj has increasingly used the formal and institutional instruments available, pressing control agencies and the São José City Council to fulfill their oversight functions. According to the Sosj, the need to work along with these agents is clear, but it is necessary to consider that the observatory was recently established and it is still in a learning process and at a time of consolidating its partnerships.

\section{The practice of co-production of information and control and the accountability process}

A summary of the conclusions regarding the practices of co-production of information and control, from the viewpoint of each category of analysis is displayed in chart 3.

Chart 3

Summary of the conclusion on co-production of information and control in three Brazilian southern cities

\begin{tabular}{|c|c|c|c|}
\hline $\begin{array}{l}\text { Category of } \\
\text { analysis }\end{array}$ & Maringá & Itajaí & São José \\
\hline $\begin{array}{l}\text { Political and } \\
\text { cultural }\end{array}$ & \multicolumn{3}{|c|}{$\begin{array}{l}\text { In the three cities, it is possible to observe a gradual adoption of the notion of accountability among the } \\
\text { observatories' staff, public servants, public agencies and local partners. This is more apparent in Maringá } \\
\text { and Itajaí, where social observatories have been working for longer. }\end{array}$} \\
\hline Valuing & \multicolumn{3}{|c|}{$\begin{array}{l}\text { Some of the partners involved clearly understand the social and political control over public } \\
\text { administration as a "social value," therefore, as a public good. This is more evident in Maringá and Itajaí } \\
\text { than in São José. However, there is a lack of knowledge, opposition, and criticism towards co-production } \\
\text { of control in some public agencies and in society portions. }\end{array}$} \\
\hline $\begin{array}{l}\text { Systemic- } \\
\text { organizational }\end{array}$ & $\begin{array}{l}\text { There are multiple interactions } \\
\text { between public and } \\
\text { community agents in the } \\
\text { production of information } \\
\text { and control; the roles and } \\
\text { governance are clearer in the } \\
\text { experience of co-production } \\
\text { under analysis. }\end{array}$ & $\begin{array}{l}\text { There are multiple interactions } \\
\text { between public and community agents } \\
\text { in the production of information } \\
\text { and control; although there is } \\
\text { opposition in some sectors (such as } \\
\text { the city council), there are potential } \\
\text { relationships to be developed. The } \\
\text { roles and governance are clearer in co- } \\
\text { production of information and control } \\
\text { under analysis. }\end{array}$ & $\begin{array}{l}\text { There is limited interaction } \\
\text { between public and community } \\
\text { agents. Progressively, the work } \\
\text { of the Sosj has pressured control } \\
\text { agencies to fulfill their roles. In } \\
\text { the experience of co-production } \\
\text { under analysis, roles and the } \\
\text { search for new governance was } \\
\text { clear, although the experience } \\
\text { has been discontinued. }\end{array}$ \\
\hline
\end{tabular}

Continua 


\begin{tabular}{|c|c|c|c|}
\hline $\begin{array}{l}\text { Category of } \\
\text { analysis }\end{array}$ & Maringá & Itajaí & São José \\
\hline Production & $\begin{array}{l}\text { Building the warehouse and } \\
\text { the inventory control system } \\
\text { involved various resources } \\
\text { and agents, revealing a } \\
\text { tangible, continuous, and } \\
\text { institutionalized co-production } \\
\text { of information and control } \\
\text { process, which may become } \\
\text { a model for other cities. } \\
\text { This experience influences } \\
\text { and is influenced by the } \\
\text { accountability system in } \\
\text { Maringá. }\end{array}$ & $\begin{array}{l}\text { There is a clear initiative of co- } \\
\text { production of information and control, } \\
\text { involving the SOI and the Public } \\
\text { Prosecutor's Office. Technical capacity } \\
\text { and trust relations established } \\
\text { between them produce concrete } \\
\text { results in terms of control, and they } \\
\text { also promote new initiatives of } \\
\text { co-production involving the Public } \\
\text { Prosecutor's Office of Santa Catarina } \\
\text { and several other observatories. }\end{array}$ & $\begin{array}{l}\text { An actual initiative to organize } \\
\text { control activities between the } \\
\text { Sosj and control agencies took } \\
\text { place along with the Municipal } \\
\text { Internal Control. Concrete results } \\
\text { were observed and the agents } \\
\text { involved could learn from it. This } \\
\text { initiative has been discontinued } \\
\text { and there were concerns in the } \\
\text { city about the role played by } \\
\text { the observatory as a part of the } \\
\text { control system. Currently, there is } \\
\text { a new relationship between the } \\
\text { Sosj and the Public Prosecutor's } \\
\text { Office. }\end{array}$ \\
\hline
\end{tabular}

Source: Prepared by the authors.

Regarding the Political and cultural category, it is possible to verify that the work done by the observatories contributes to incorporate the notion of accountability in public administration. This process, however, is not linear. There are advances, stagnation, and setbacks in terms of trust among the agents, shared activities, and results.

When it comes to the valuing category, the work done by the observatories contributes in order for control to be considered as a public good, which is co-produced through the involvement of several agents. Some public agents and citizens appreciate the engagement of the observatory and other social organizations in the production of information and control, but there is a certain degree of ignorance, skepticism, opposition, and criticism among some public administration agents and society sectors. These barriers are often overcome because of the technical quality of the work done by the observatories, due to the capacity of observatories for political mobilization, the trust inspired by the attitude of leaders in the observatories, the openness of some public servants, and the results obtained by the work.

In the systemic-organizational category, in Maringá and Itajaí a clearer definition of the process and roles of those involved in the control system is observed, especially in the initiatives of co-production under analysis. In São José, this relationship is at the prior stage of construction. In the three cities, there are multiple interactions between government and community agents in the production of information and control, although there is not always defined governance. There are initiatives of observatories to demand and pressure public officials to fulfill their specific functions within the local accountability system.

In the production category, a variety of degrees and ways of co-production of information and control is observed in the three cities. The experience of Maringá by using a warehouse shows co-production in a rather clear way because of its tangibility, continuity, resources, and agents involved, as well as the institutionalization degree. In Itajaí, the relationship between 
the SOI and the Public Prosecutor's Office is not fully institutionalized, yet, it still depends on the profile or the action taken by their leaders. However, the experience of Itajaí has obtained concrete results and increased trust and opportunities for new relationships of co-production involving other observatories and municipalities.

Even in experiences of co-production that are not continuous (those that operate for a specific period, achieve results, and then are terminated), such as in São José, agents are able to learn about the way how the control system works, something which provides the observatories with skills to influence it. This means that when co-production brings together the public and community agents, it promotes trust and generates knowledge, which are both crucial for the incorporation of accountability in the local political culture. This also influences the same procedures in other cities, through the activities of observatories interconnected within a network and the connection between control agencies in several states.

There is a relationship of a mutual influence: the multiplicity of interactions in the accountability system generates opportunities for co-production; experiences of coproduction expand the capacity of public and community agents to understand and act on the system itself. The system benefits from new dynamics not only at the local level, but also at the institutional-national level (control rules, laws, and institutional mechanisms). These innovative experiences taking place in each local context generate learning and knowledge that are widely disseminated.

The experiences show the slow and progressive incorporation of the concept of accountability in the Brazilian political culture, in a process that is heterogeneous, contradictory, and nonlinear, combining old and modern values (Campos, 1990; Pinho and Sacramento, 2009). The features observed are primarily those of stage 2 (cross-sectional accountability), where co-production of information and control happens in a non-systemic way. There is also evidence of stage 3 (systemic accountability), where there are multiple interactions between institutional control and social control, with several degrees of regularity and resource sharing, influencing the State structure and the limits of its action.

Within the network SOB, the predominant elements found are those at stage 2. Their work seeks to create a favorable environment, where interactions between the observatories and the agencies of institutional control are rather fluid, dynamic, and continuous. The answers obtained from the questionnaire applied to twenty observatories show, however, that most interactions happen with the city halls and city councils, with a focus on controlling bids and quantitative monitoring of legislative production, although the practices of some observatories show some features of stage 3.

Some observatories under study have obtained significant results in fighting corruption and monitoring public administration activities. Others, however, face basic institutional difficulties, such as problems to raise funds, low operational capacity to undertake the activities needed and to communicate to society and government agencies. This situation weakens the observatories' representation and legitimacy within the society and, as a consequence, their capacity to exercise influence. Generally, it may be argued that these organizations contribute, at different degrees, to fiscal education and to local social control, and they also open spaces 
for co-production of public administration control. The activities of social observatories demonstrate the potential for innovation in public administration practices, because they engage various organizations and citizens in improving public administration, working within a network, and strengthening co-production of public services.

In Maringá, there is a mutual engagement of citizens and public servants in co-production of information and control, as well as a set of multiple connections between the mechanisms of institutional and social control and its agents, which reflects stage 3 of the model of analysis - systemic accountability. The diverse interactions, in several ways and degrees of institutionalization, affect the operation of the State function, including the institutional and administrative-operational organization, and help shaping the State structure and making the limits of its action more fluid and permeable.

Itajaí and São José are between stages 2 and 3. The elements of stage 2 - cross-sectional accountability - are observed in both: the production, dissemination, and use of good-quality information to exercise control by public agents and citizens. To some extent, there is an interaction between vertical and horizontal mechanisms of control, creating new ways of control and a new axis of control over State and government activities. An example is how the experience of co-production in Itajaí has led other observatories to work with the Public Prosecutor's Office, just as in a recent partnership agreement signed to monitor the municipal web portals together.

There is, therefore, co-production of information and control, but it is marginal to the system. The State apparatus resumes most of the responsibility for production of information and control. There is, however, the progressive presence of elements from stage 3 . There are interactions between one or more mechanisms of institutional and social control with different degrees of regularity and resource sharing, with a consequent expanded capacity of influence of social control over the institutional control system. In some situations, a mutual engagement between citizens and public servants hinders accomplishing the State functions, influencing the State structure and the limits of its action.

Slowly, the local accountability system becomes rather organic, with interdependence between parties, with resilience even when any of the parts fails. The institutional agencies recognize the relevance of the work done by the social observatories and they reveal some criticism, as the latter are regarded as "politically influenced." There is also a need for more closeness and collaboration of institutional control agencies between themselves: city councils, State Court of Auditors, Public Prosecutor's Office and Municipal Internal Control. They do not always dialogue and seek interconnected solutions to improve information and control. They are often activated only when pressured by social control, something which does not always happen.

\section{Conclusion}

Through the development of a proposal to categorize accountability into four stages — classical, cross-sectional, systemic, and diffused -, this research aimed to identify characteristics of co- 
production of information and socio-political control over public administration by Brazilian social observatories, considering their relationship with government control agencies. Data from twenty social observatories in Brazil and three experiences of co-production of information and control were described and analysed herein.

According to a systemic approach to accountability, there is a relationship of mutual influence: the multiplicity of interactions in the system forges co-production; when coproduction occurs, it increases the capacity of public and community agents to understand and act on the system itself, qualifying the system and making it more dynamic. Similarly, there is a relationship of mutual influence at the institutional-national level, where new institutional mechanisms have been built, promoting information and control (laws, agencies, interactions, training). On the other hand, innovative experiences happening in each local context, where what is learned is disseminated to other contexts, influence the political and accountability culture in the country as a whole. The systemic nature of accountability is clear in the various possible combinations between top-down and bottom-up perspectives.

The experiences under analysis showed the limits of the traditional relationship between vertical-horizontal axes as a reference for understanding the relationships between agents and mechanisms of control and they point to co-production of information and control as a real - although challenging — possibility. The typology of accountability stages proposed may contribute to advancing the understanding of the practices and systems, however, there is a need to improve and test it in various contexts, as well as to seek new theoretical frameworks, in dialogue with recent studies about social accountability and relational accountability. The same is true for the model of analysis of co-production of information and control, which still remains to be tested and refined in various contexts.

Civil society mobilizes and connects to government at the local and national level, contributing to activate the accountability system and achieve better results in terms of information, justification, reward, and punishment. This is not homogeneous among the various municipalities. Although the same institutional and methodological resources are available, the degree of engagement, the profile of those involved, and the quality of relationships between agents in each context influences accountability.

The analysis of three cities stresses that, for establishing co-production of information and control, it is crucial that, besides the engagement of civil society, there are public servants open to dialogue and co-production along with the society, in order to facilitate and open communication channels between institutional control and social control. It was observed in some situations that public servants, who know the control system and face constraints to change them from inside out, often seek observatories as a strategy to act.

This research, conducted in three cities, highlights the importance of co-production of information and control, the influence of social control to activate the institutional control system, and the effects of interactions between government and community in defining the kind of accountability that each city is able to build. This reinforces the assumption that the continuous and dynamic interaction between agencies of institutional control, particularly when co-production is organically connected to the process, tends to produce better outcomes 
both for government agencies and for social control, thus it is more effective to promote accountability.

Finally, we may claim that the development of accountability is an ongoing process in Brazil, and experiences such as the network SOB and the three cities under analysis contribute to boost this process. Therefore, even when continuity and institutionalization are not achieved, these experiences enable the observatories to learn how to activate the system of institutional control and be more effective in their work. In this way, they find out system operation details and build ties with civil servants who value control as a public good coproduced through an interaction between the State apparatus and citizens.

\section{References}

ABRUCIO, Fernando L.; LOUREIRO, Maria R. Finanças públicas, democracia e accountability. In: ARVATE, Paulo R.; BIDERMAN, Ciro. Economia do setor público no Brasil. Rio de Janeiro: Elsevier; Campus, 2005. p. 75-102.

BEHN, Robert D. O novo paradigma da gestão pública e a busca da accountability democrática. Revista do Serviço Público, v. 49, n. 4, p. 5-45, out./dez. 1998.

BRUDNEY, Jeffrey L.; ENGLAND, Robert E. Toward a definition of the coproduction concept. Public Administration Review, v. 43, n. 1, p. 59-65, jan./fev. 1983.

CAMPOS, Ana M. Accountability: quando poderemos traduzi-la para o português? Rev. Adm. Pública, v. 24, n. 2, p. 30-50, fev./abr. 1990.

CENEVIVA, Ricardo. Accountability: novos fatos e novos argumentos - uma revisão da literatura recente. In: ENCONTRO DE ADMINISTRAÇÃO PÚBLICA E GOVERNANÇA DA ANPAD, ENAPG, 2006, São Paulo. Anais... São Paulo: Anpad, 2006.

CHILD, John; McGRATH, Rita G. Organizations unfettered: organizational form in an information-intensive economy. Academy of Management Journal, v. 44, n. 6, p. 1135-1148. dec. 2001.

CIDER. Centro de Estudios Interdisciplinarios Sobre el Desarrollo. Análisis y estudio de experiencias de accountability social en américa Latina. [Informe final de investigación]. Bogotá, 2011. Available at: < http://ahernand.uniandes.edu.co/Documentos/INFORME_FINAL_ACCOUNTABILITY_SOCIAL2011.pdf>. Access on: 4 Aug. 2014.

DENHARDT, Janet V.; DENHARDT, Robert B. The new public service: serving, not steering. New York: M. E. Sharpe, 2003.

DENHARDT, Robert B. Teorias da administração pública. São Paulo: Cengage Learning, 2012.

DOIN, Guilherme A. et al. Mobilização social e coprodução do controle: o que sinalizam os processos de construção da Lei da Ficha Limpa e da Rede Observatório Social do Brasil de Controle Social. Pensamento \& Realidade, v. 27, n. 2, p. 56-79, 2012. 
FOX, Jonathan. Social accountability: what does the evidence really say? Global Partnership for Social Accountability, GPSA Working papers series, n. 1. Washington: GPSA. Sept. 2014. Available at: <http://gpsaknowledge.org/knowledge-repository/social-accountability-what-does-the-evidence-really-say-2/\#.VWDegk9VhBc> . Access on: 23 May 2015

GOETZ, Anne M.; JENKINS, Rob. Hybrid forms of accountability: citizen engagement in institutions of public-sector oversight in India. Public Management Review, v. 3, n. 3, p. 363-83, 2001.

HEIDEMANN, Francisco G. Ética de responsabilidade: sensibilidade e correspondência a promessas e expectativas contratadas. In: HEIDEMANN, Francisco G.; SALM, José F. (Org.). Políticas públicas e desenvolvimento: bases epistemológicas e modelos de análise. Brasília: UnB, 2009. p. 301-309.

KEANE, John. The life and death of democracy. London: Simon \& Schuster, 2009.

KISSLER, Leo; HEIDEMANN, Francisco G. Governança pública: novo modelo regulatório para as relações entre Estado, mercado e sociedade? Rev. Adm. Pública, v. 40, n. 3, p. 479-499, maio/jun. 2006.

KLUVERS, Ron; TIPPETT, John. Mechanisms of accountability in local government: an exploratory study. International Journal of Business and Management, v. 5, n. 7, p. 46-53, Jul. 2010.

KOPPELL, Jonathan G. S. Pathologies of accountability: Icann and the challenge of "multiple accountabilities disorder". Public Administration Review, v. 65, n. 1, p. 94-108, jan./fev. 2005.

LOUREIRO, Maria R. et al. Do controle interno ao controle social: a múltipla atuação da CGU na democracia brasileira. Cadernos Gestão Pública e Cidadania, v. 17, n. 60, p. 54-67 jan./jun. 2012.

MARSCHALL, Melissa. Citizen participation and the neighborhood context: A new look at the co-production of local public goods. Political Research Quarterly, v. 57, n. 2, p. 231-244, jun. 2004.

MARULANDA, Nohra R.; TANCREDI, Francisco B. De la inovación social a la política pública: historias de éxito en América Latina y el Caribe. Santiago del Chile: Naciones Unidas - Cepal [Colección Documentos de proyectos], 2010. Available at: <www.cepal.org/publicaciones/xml/2/41582/ innovacion-social-politica-publica-2010.pdf>. Access on: 23 May 2015.

MONCRIEFFE, Joy. Relational accountability: complexities of structural injustice. London; New York: Zed Books, 2011.

OBSERVATÓRIO SOCIAL DO BRASIL. Institucional. Available at: <www.observatoriosocialdobrasil. org.br/>. Access on: 14 May 2014.

O’DONNELL, Guilhermo. Accountability horizontal e novas poliarquias. Lua Nova, São Paulo, v. 44, p. 27-54, 1998.

PINHO, José A. G.; SACRAMENTO, Ana R. S. Accountability: já podemos traduzi-la para o português? Rev. Adm. Pública, v. 43, n. 6, p. 1343-68, nov./dez. 2009.

RAMOS, Alberto G. A nova ciência das organizações. São Paulo: FGV, 1981.

RHODES, Roderick A. W. Policy network analysis. In: MORAN, Michael; REIN, Martin; GOODIN, Robert. The Oxford handbook of public policy. New York: Oxford University Press, 2006. 
ROBERTS, Nancy. Public deliberation in an age of direct citizen participation. The American Review of Public Administration, v. 34, n. 4, p. 315-353, dez. 2004.

ROCHA, Arlindo C. Accountability na administração pública: modelos teóricos e abordagens. Contabilidade, Gestão e Governança, v. 14, n. 2, p. 82-97, maio/ago. 2011.

ROCHA, Arlindo C. et al. A coprodução do controle como bem público essencial à accountability. In: ENCONTRO DA ASSOCIAÇÃO NACIONAL DE PÓS-GRADUAÇÃO E PESQUISA EM ADMINISTRAÇÃO, 2012, Rio de Janeiro. Anais... XXVI: Anpad, 2012.

SALM, José F.; MENEGASSO, Maria E. Proposta de modelos para a coprodução do bem público. In: ENCONTRO DA ASSOCIAÇÃO NACIONAL DE PÓS-GRADUAÇÃO E PESQUISA EM ADMINISTRAÇÃO, XXIV, 2010, Rio de Janeiro. Anais... Anpad, 2010.

SCHOMMER, Paula C.; DAHMER, Jeferson; SPANIOL, Enio L. Controle social no Brasil: estadocêntrico ou sociocêntrico? Evidências da 1aㅡ Conferência Nacional sobre Transparência e Controle Social, Consocial. Revista Administração Pública e Gestão Social, v. 6, n. 1, p. 1-55, jan./mar. 2014.

SCHOMMER, Paula C.; NUNES, Jonas T.; MORAES, Rubens L. Accountability, controle social e coprodução do bem público: a atuação de vinte observatórios sociais brasileiros voltados à cidadania e à educação fiscal. Publicações da Escola da AGU: Gestão Pública Democrática, Brasília, v. 4, n. 18, p. 229-258, maio/jun. 2012.

TREVISAN, Antoninho M. et al. O combate à corrupção nas prefeituras do Brasil. Cotia: Ateliê Editorial, 2003.

VERSCHUERE, Bram; BRANDSEN, Taco; PESTOFF, Victor. Co-production: the state of the art in research and the future agenda. Voluntas, v. 23, n. 4, p. 1083-1101, jul. 2012.

Paula Chies Schommer has a PhD in administration, she is a professor at Santa Catarina State University/ Center of Administration and Socioeconomics Sciences/Department of Public Administration (Udesc/ Esag/Dap), and member of the Research Group Politeia: Co-production of Public Good — Accountability and Management. E-mail: paula.schommer@udesc.br.

Arlindo Carvalho Rocha has a PhD in administration, he is a professor at Santa Catarina State University/ Center of Administration and Socioeconomics Sciences/Department of Economic Sciences (Udesc/Esag/ DCE), and member of the Research Group Politeia: Co-production of Public Good - Accountability and Management. E-mail: arlindo.rocha@udesc.br.

Enio Luiz Spaniol has a PhD in political sociology, he is a professor at Santa Catarina State University/ Center of Administration and Socioeconomic Sciences/Department of Public Administration (Udesc/ Esag/Dap), and member of the Research Group Politeia: Co-production of Public Good — Accountability and Management. E-mail: elspnl@yahoo.com.br.

Jeferson Dahmer has a bachelor degree in public administration, a masters in administration at Santa Catarina State University/Center of Administration and Socioeconomics Sciences (Udesc/Esag), he is a member of the Research Group Politeia: Co-production of Public Good - Accountability and Man- 
agement, and member of the Network of Political Action for Sustainability (Rede de Ação Política pela Sustentabilidade — Raps) in Civic Entrepreneurs group. E-mail: jeffedahmer@gmail.com

Alessandra Debone de Sousa has a bachelor degree in public administration at Santa Catarina State University/Center of Administration and Socioeconomics Sciences (Udesc/Esag), she was a junior researcher between 2011 and 2012 for the Research Group Politeia: Co-production of Public Good — Accountability and Management, and is currently the monitoring coordinator of the Program Mãe Coruja Pernambucana, Government of the State of Pernambuco. E-mail: ale.debone@gmail.com. 